\title{
Solar Decathlon. Interdisciplinary and collaborative research competing on a world stage
}

\author{
Guy Marriage \\ Victoria University of Wellington, New Zealand \\ School of Architecture, \\ guy.marriage@vuw.ac.nz
}

\begin{abstract}
The Solar Decathlon is an international student competition requiring university-led interdisciplinary student teams to research, design, build and operate a solar-powered house. Projects like this are highly competitive but have significant learning benefits for those involved. The Decathlon requires a wide range of student skills and so is by nature highly interdisciplinary. To win requires a significant amount of collaboration between team members who must rapidly accumulate specialised knowledge of diverse fields including solar design. This paper looks at the Solar Decathlon 20I I project submitted by Victoria University of Wellington, New Zealand, examines the pedagogical methodologies used, and debates the usefulness of this type of interdisciplinary and collaborative project for students of a school of architecture. It notes the difficulties placed on integration of a single-project focus on the wider scope of a typical architectural education and proposes that the broader degree curriculum may benefit from evolving to better accommodate the flexibility needed for targeted design-led research competitions such as the Solar Decathlon.
\end{abstract}

Keywords: solar powered, modular house, student project, collaborative design.

To cite this article:

Marriage, G. (20I7). Solar Decathlon. Interdisciplinary and collaborative research competing on a world stage. The Journal of Public Space, 2(3), Special Issue, 3I-40, DOI: 10.5204/jps.v2i3.II I

This article has been peer-reviewed and accepted for publication in The Journal of Public Space. Please see the Editorial Policies under the 'About' section of the journal website for further information. 


\section{Introduction}

The Solar Decathlon is the biggest architectural student competition in the world. The aim is for student-based teams to design-build a small house and run it solely using solar power for the course of the competition. Started in 2003 by the United States Department of Energy (DoE) and run bi-annually since then, the Solar Decathlon pits student teams against each other in a series of competitions. The word Decathlon in the title is used deliberately there are 10 competitions (five judged by experts, five scored on points by independent judges) held over 10 days with winning podium places equivalent of bronze, silver and gold medals. As a form of design-led research and an implementation of theory into collaborative practice, this is the ultimate challenge for students. The program has effectively become embedded in many USA schools of architecture, with success at the Solar Decathlon seen as the pinnacle of achievement. A key issue for competing schools of architecture, however, is that the current pedagogical systems in place at most universities is via a series of individual courses, undertaken by students one term at a time and not readily adaptable to one large project such as the Decathlon.

Changing the curriculum in order to fit the very different requirements of the Solar Decathlon is therefore part of the challenge, where a large group of students are required to work continuously and highly collaboratively, rather than compete for marks individually. As a project, the Solar Decathlon is very different to the normal design exercises held in architecture schools, where designs are typically conceived on paper and remain in twodimensional form. Actual, physical, real-life buildings are exceptionally rare as an output of an academic experience. A more typical academic experience would be for a student to have to take a number of small, specialised papers on aspects such as professional practice, methods of construction, ventilation and heating, sustainability, and of course design. In many modern schools the student could graduate without having ever had to use a hammer, or in some cases, to even see one. To succeed at the Solar Decathlon requires different means of teaching. This chapter uses the example of the 'Team New Zealand' entry in 201 I to illustrate the issues.

\section{Competition aims}

The aims of the competition are focused on raising public awareness about alternative energy sources, and up-skilling the architectural student population. The teams comprise primarily architecture students and services engineering students, but are open to all and thus provide an excellent opportunity for student collaborative and interdisciplinary relationships to become established and expanded.

The competition requires each team to design and build a house, assemble it within a week, and run the whole house for ten days solely off solar power generated on site. It requires extensive interdisciplinary collaboration between different streams of students and, as a form of design-led practice, it is an excellent learning tool. Asking a group of semi-skilled architectural students to design and build a house to the following brief is a lofty aim:

- Build a modular house and transport it several hundred (or thousand) of kilometres across the country;

- Assemble or reassemble the house in just five days on a blank site with no permanent power or sewerage; 
- Run the house entirely off solar power for a period of ten days, while also performing standard "living" tests (washing, cooking, entertaining, etc.), and then escorting 10,000 or more visitors through the house over a three day period, while maintaining the highest health and safety conditions;

- Disassemble the house entirely in four days and remove it, leaving no trace except for some bent blades of grass.

It is a big event on the student horizon - every mobile crane company for many miles around is fully booked by Solar Decathlon participants for the assembly / disassembly phases, with typically 20-30 mobile cranes present on site for the initial night of installation. Each year millions of dollars are spent corralling efforts around this program, and each year some teams fail to complete some of the tasks or even drop out of the competition completely. To add to the difficulty, all the work on site must be undertaken by enrolled students - no mean feat when most of the students on the teams are only 2-3 years out from high school. At Victoria University, the students were drawn from the schools of Architecture, Design, and Marketing, with further input from the programs of Building Science, Interior Architecture, Digital Media, Landscape Architecture, Industrial Design and Tourism. Faculty advisors are limited to certain roles off-site such as administration, while professional tradespeople are limited to restricted work such as electrical wiring, as the aim of the competition is for the next generation of architecture and engineering students to learn about the practical side of house construction. In turn, these young students will become the new leaders in the emerging solar-based economy. While those aims are admirable, there are issues with how these aspirations can fit with and co-exist within a 'usual' university degree structure.

\section{Teaching architecture}

Teaching architecture via a degree at a university is a relatively new means of learning. Traditionally, budding young student architects were articled to older, more experienced architects, often paying for the privilege: similarly, young builders were apprenticed to older builders. Architects faithfully copied classical details to adorn their buildings, as did their builders. The establishment in London of the Architecture Association in 1890 started the split away from practice towards academia and offered a reaction against the perceived poor ethics of articled students, while encouraging the relative freedom of academic thought. The establishment of the Bauhaus in 1919 in Weimar introduced modernism to the architectural world, coinciding with the decline of architecture designed in a Beaux-Arts style. The decline of the Beaux-Arts training methods of studying and reproducing classical motifs occurred around the same time and were mirrored by the rise of the more modern system of creative architectural studios, pioneered by the art studios of the Bauhaus, led by Walter Gropius (Director from 1919 to 1928) and later Mies van der Rohe (Director from 1930 to 1933). The Bauhaus methods of teaching emphasised the artistic merits of designs as well as the craftsmanship of their construction and introduced the design studio as the prime method of teaching architecture for the modern age. This teaching style spread rapidly across Europe and later worldwide. 


\section{Balancing academic and non-academic skill sets}

The modern architecture student is not trained as a builder, and is therefore typically lacking in hands-on knowledge of the practical skills of building. There is in New Zealand little or no working interface between building apprentices and university architecture students; in effect, the two groups learn different subjects, and speak different languages. It is important that the students learn that the two sides need each other and need to learn to work together. For this reason, students in the Solar Decathlon and other programs (such as Rural Studio in Alabama or Studio 19 at Unitec in Auckland) are eager to integrate their academic learning with the acquisition of practical skillsets. This hands-on learning is in strong contrast to that of a typical modern school of architecture, where increasing class sizes and increasingly onerous Health and Safety regulations are having a deleterious effect on practical aspects such as site visits and workshop work.

\section{First Light team}

The brief from Professor Patrick Walsh, the Pro-Vice-Chancellor (PVC) at Victoria, was simple: "go there, and win".' That dictum drove the team onwards - but the universitysponsored Project Managers instead promoted the concept that keeping to a nominal budget was of the uppermost importance. The PVC had notably not said -"go there and win on a limited budget". To fully cover the scope of what happened in the competition is beyond this paper and has been covered extensively in other publications. Instead, this paper is focused on the pedagogical aspects of incorporating a project such as this into the standard learning objectives and teaching methods of a school of architecture.

For Victoria University students, the 2009 Solar Decathlon was used as the framework for an interdisciplinary studio design elective course. The assignment brief was to take the aims of the Solar Decathlon and to design a house that would meet the brief - a strictly paperbased assignment of a few weeks duration. Groups of four students were put together randomly, and each team produced a house design that met the brief. The strongest design, First Light, by Anna Farrow, Benjamin Jagersma, Eli Nuttall and Nicholas Officer, was entered into Solar Decathlon 20II with the tentative support of the University, who perhaps did not realise the size and scale of the project ahead. Students signed up from Architecture,

Building Science, Digital Media, Industrial Design, Marketing, Tourism, Landscape Architecture, and Interior Architecture - and only the most passionate, capable and hardworking of those went forward into the final selected team.

The First Light team entry was selected by the competition organisers as one of twenty that would compete on this international stage in $20 \mathrm{II}$ against the other best university entries from around the world. The nineteen other student teams selected included one from China, one from Canada, and one from Belgium, with all other challengers coming from the United States - primarily from nearby East Coast states, but also including an entry from California and one from Hawaii. All student teams were interdisciplinary, and some universities even collaborated with others - for instance, SCl-ARC (a University entrant) was partners with Cal-Tech (a Technical Institute). The New Zealand entry was the first ever entry to be accepted from the Southern Hemisphere and therefore the furthest away

\footnotetext{
' Pat Walsh - speech to the student team (Wellington, Victoria University, May 20I I).
} 
entrant ever. To compete on this world stage would prove to be a considerable challenge, requiring significant collaboration amongst the students and faculties involved.

The student team had to not only design and build the project, they had to go out and sell the scheme to raise the money as well. Marketing and tourism student experience on the team was hugely useful, as an extensive media presence had to be created, but in the end, the four original architecture students still undertook the vast bulk of the public relations work as well as leading the design and documentation of the project. Jagersma became the specialist in building services systems, while Officer concentrated on the promotion and management of the project. Nuttall took control over the construction of the actual house, while Farrow masterminded both the interior fit-out and the external landscape. None of these roles were their original focus within the School of Architecture, but by collaboratively working together as a tightly focused team, the project was a great success. The collaborative method of learning, with all students working towards a common goal (instead of competing against each other for better grades) seemed to result in a much stronger outcome for the student cohort. The team succeeded in getting sponsorship for almost the entire project, both for individual elements (e.g., doors and windows sponsored by EcoWindows) and the overall scheme (the project becoming officially known as the Meridian First Light House).

In the end, the project competed at an extremely high level, with the First Light House winning First Prize in Engineering, Energy Balance, and Hot Water generation; a tantalizingly close Second Prize in Architecture, and Third Prize in Market Appeal; as well as Third Prize overall. The first for Engineering was particularly pleasing for the team as no engineering students were involved in the project. Specialist knowledge on this subject was obtained by Jagersma and the Building Science students working in close collaboration with industry professionals. The result speaks to the quality of work undertaken by students from both architecture and building science, as well as the input from interdisciplinary practices such as Stephenson \& Turner. Academic staff members have covered the competition in papers published over the past few years (Danielmeier, 201 I ${ }^{2}$, Marriage, $2010^{3}, 201 I^{4}, 2012^{5}$ ). The project also attained First Prize in Clever Wood Solutions at the NZ Timber Design Awards in $20 \mathrm{II}$ and won a New Zealand Architecture Award for International Architecture at the NZIA awards in 2013 - the only time a student project has ever won the top NZIA award. The four original students completed their work as Master of Architecture thesis projects (Farrow, 20I2; Jagersma, 20I2; Nuttall, 20I2; Officer, 20I2). The four student theses tell the story behind the story: each of the students examining a different aspect of the project,

\footnotetext{
${ }^{2}$ Tobias Danielmeier, "Communication Strategies for the Solar Decathlon 20II - Lessons from the New Zealand Entry First Light House” (Australia: Australian Solar Energy Society, 20I I Guy Marriage, "Building Reality: Results from the FirstLight House Student Project," 45th Annual Conference of the Australian and New Zealand Architectural Science Association (Sydney, ANZAScA, 20I I); Guy Marriage, "First Light: Reflection on Prefabrication," 46th Annual Conference of the Australian and New Zealand Architectural Science Association, (Griffith, ANZAScA, 20I2).

${ }^{3}$ Guy Marriage, "Building the First Light house: applied research in sustainability". 44th. Annual Conference of the Architectural Science Association, (Auckland, ANZAScA, 2010).

${ }^{4}$ Guy Marriage, "Building Reality: Results from the First Light House student project". 45th. Annual Conference of the Australian and New Zealand Architectural Science Association, (Sydney, ANZAScA, 20I I).

${ }^{5}$ Guy Marriage, "First Light: Reflection on Prefabrication". 46th. Annual Conference of the Australian and New Zealand Architectural Science Association, (Griffith, ANZAScA, 20I2).
} 
closely following their primary roles in the project. Farrow's thesis $(2012)^{6}$ examines the work to the interior, Nuttall $(2012)^{7}$ writes of the planning logistics and building of the project, Jagersma $(2012)^{8}$ details the mechanical, electrical and seriously technical parts of the project, while Officer $(2012)^{9}$ discusses the trials and tribulations of trying to select the right management structure to guide the project. As would be expected on a project of this complexity, all of these aspects had issues at various times, and indeed the project is revealed to have been at the brink of cancellation on more than one occasion. What may have saved it is that the project was bigger than just a single faculty and had critical buy-in from all the other collaborating faculties involved. The interdisciplinary aspect of the project ensured some form of stability.

\section{University profile enhancement}

The University's aims for the Solar Decathlon project have never been fully outlined publicly. While support from the higher echelons of the University was readily forthcoming in the backing of the project and the mandate to 'go there and win', there were perhaps further unwritten goals for First Light. One of these was to raise the public and global profile of the University. This was achieved; the First Light project was highly successful at raising awareness via many different media. Official media releases had to conform to the dictates of the Solar Decathlon governing body in the USA, and thanks to the media team at First Light, media interest was high. The high quality graphic standards of the project were rigidly enforced through guidance from Chris Meade at Designworks. The high technical standards achieved are attributable to the excellent support that the team received from key sponsors such as Leap (hot water), Mitsubishi Black Diamond (solar cells), and Fisher \& Paykel (electrical appliances). For instance, Mark Elmore, technical director at Fisher \& Paykel, authorised a special production of a 2-burner ceramic induction hob for the project, hitherto not available to the New Zealand market. The whole project was, in public relations terms for the University, money well spent on raising the public profile of the University and attracting more foreign students to the Schools of Architecture and Design. Arguably, the project is the most high-profile student architectural project ever staged by a New Zealand university.

\section{Pedagogical challenges and successes}

Attempting to retrofit the project into a standard university course structure was problematic. The standard arrangement of courses in the BArch, BAS and BBSc degrees at Victoria University was devised to give students a rounded education through set courses that span the breadth of several years, through trimesters of twelve weeks each. The First Light project, on the other hand, required a continual presence of up to thirty hand-chosen

\footnotetext{
${ }^{6}$ Anna Farrow, “Inside the First Light House: Interior Design for New Zealand's Entry into the U.S. Department of Energy's Solar Decathlon 20I I" (Wellington, Victoria University, 20I2).

${ }^{7}$ Eli Nuttall, “The First Light House: Logistics and Construction: Victoria University of Wellington's Entry into the U.S. Department of Energy Solar Decathlon 20I I" (Wellington, Victoria University, 20I2).

${ }^{8}$ Ben Jagersma, "The 10 day bach: A net zero energy home: A story of the design and operation of the First Light house in the 20I I Solar Decathlon” (Wellington, Victoria University, 20I2).

9 Nicholas Officer, “Everything but the building: Project Organisation, the First Light house, Solar Decathlon 201 I" (Wellington, Victoria University, 20I2).
} 
students to work for up to a year designing, drawing and constructing a single project - an intensely technological one-bedroom house powered solely by the sun. The standard model of students being present for twelve weeks and then going away on a three-month long summer break was not appreciated by the organisers of the project, who faced periods of their workforce having to go back to their home towns to work over the university holiday period to finance their studies. The continuity and commercial reality of a real-life project is in strong contrast to that of the typical student architecture school experience, where projects are experimented on in studio, with sketchy drawings produced and artistic renditions captured, but no real live testing of the design concepts are produced as a full-size built finished product. Here, the reality of one finished building, complete down to the last screw and bolt, was an intense learning experience beyond what any of the students had attempted (or completed) before.

Despite these difficulties, the pedagogical success of this project was significant. The leading four students completed MArch degrees based on the Solar Decathlon project. Knowledge acquisition by these four students was intense and diverse, including: dealing with CEOs of major companies (hence overall key project sponsorship by Meridian Energy), presentations to over 50 different companies and industry organisations, regular meetings with the ViceChancellor and the Pro-Vice-Chancellor as well as weekly meetings with the Head of School, meetings and presentations with the former Prime Minister (Hon. Helen Clark), Minister of Finance (Hon. Bill English), Government Science Advisor (Dr. Peter Gluckman), the New Zealand Ambassador to the USA (Hon. Mike Moore), etc. This core team of four young architectural graduates has gone on to develop their own company First Light Studio (FLS) and are now working in a highly collaborative manner within the prefabricated housing industry.

Most importantly, the wider team of 26 students on the project also gained significant benefits. Hard work was undertaken for long hours, and 4-8 weeks spent in Washington D.C. assembling, running and disassembling the house, through the mechanism of new, multidisciplinary, elective courses set up by the School of Architecture, with specifically First Light oriented objectives. Issues such as a maximum number of elective courses also came into play, with students disinclined to enrol in further courses if they could not accumulate credits that they could use on their current degree. Other issues included the stark reality that the Solar Decathlon competition required a dedicated member of the team to be the Health and Safety Officer (HSO) - so while some members of the team got to design and draw and build, the HSO instead had to sit and watch safety videos in order to pass the USA's required level of safety standards: ultimately far less fun.

Students still had to complete their regular studies as well, and some lecturers seemed at times unaware of the significance or importance of competing in the Solar Decathlon project. Requests for leniency and alternative assessment methods to meet course objectives were not always met with agreement and in some (rare) cases, students had to drop courses so that they could partake in the First Light project. As an example of a more collaborative approach, an alliance was set up with Fanshawe College in London, Ontario (who had not been successful in entering the Solar Decathlon themselves, but both their staff and students were keenly willing to help), volunteering to twice drive a return trip of $1700 \mathrm{~km}$ across North America to assist in the project assembly and disassembly phases. The most important aspect to consider is the benefit to the students across the wider school. With some architecture classes re-oriented towards the First Light project, there 
was a perceived risk that the more regular projects normally undertaken (e.g. a regular project such as design of a museum or art gallery) were not being covered by a project which, no matter how complex it seemed, was still just a very small house. Educators needed to balance the learning outcomes of being involved with a high stakes collaborative and interdisciplinary project such as First Light and the subsequent acquisition of specialised knowledge in that small field, with the wider view - albeit less intensely focused - afforded by a regular, more general project topic. Coupled with this was the knowledge that while 20-30 students were selected to go overseas to work on the house project in Washington D.C., the remaining 100-200 students from their year would not leave New Zealand. Was the experience of the remaining stay-at-home students worth the extra hard work? The general consensus of the students involved appears to be "Yes!" Despite not making it into the final group bound for the USA, there still was a strong sense of residual pride that they were involved with a world-class project of this sort, an unparalleled awareness of the interdisciplinary components of a complex project, and a significant addition to their C.V.

\section{Alternative routes to success}

Following the success of the VUW entry, Australian universities also became interested in entering the Solar Decathlon competition. Representatives from University of Wollongong (UoW) came to New Zealand to discuss the way forward with representatives from VUW, and it was evident that they had one significant advantage over the VUW model - they already had a team structure at UoW that tackled a large collaborative project every year. For UoW, their regular project at the School of Engineering was to design, build, and run the resulting car in the Formula SAE Grand Prix. Wollongong's success and continual involvement in Formula SAE has left the University with significant institutional knowledge on how to run an annual student-based learning project. This was evident in UoW's entry "Illawarra Flame" to the 2013 Solar Decathlon China competition, where they succeeded in taking out the First Prize overall, beating all the home territory Chinese teams.

UoW succeeded by collaborating with another tertiary institution, the local TAFE (Technical and Further Education) technical college. In the 201 I competition, an equivalent pairing with VUW might have been to team with students from WelTec, or Whitirea Polytechnic, or with the Schools of Engineering at the University of Auckland or Canterbury. For a number of reasons, this did not happen. Instead, a construction company Mainzeal was contracted to build the house for VUW (despite Mainzeal not being a residential builder). Awkwardly, shortly after the completion of the project (but for wholly unrelated reasons), Mainzeal went into bankruptcy, collapsed and disappeared; thus the chance to commercialise the First Light House at that stage was lost. Happily, the loss of Mainzeal has meant that the four original graduates in First Light Studio have picked up that role and continue to commercialise the successor to the First Light House. 

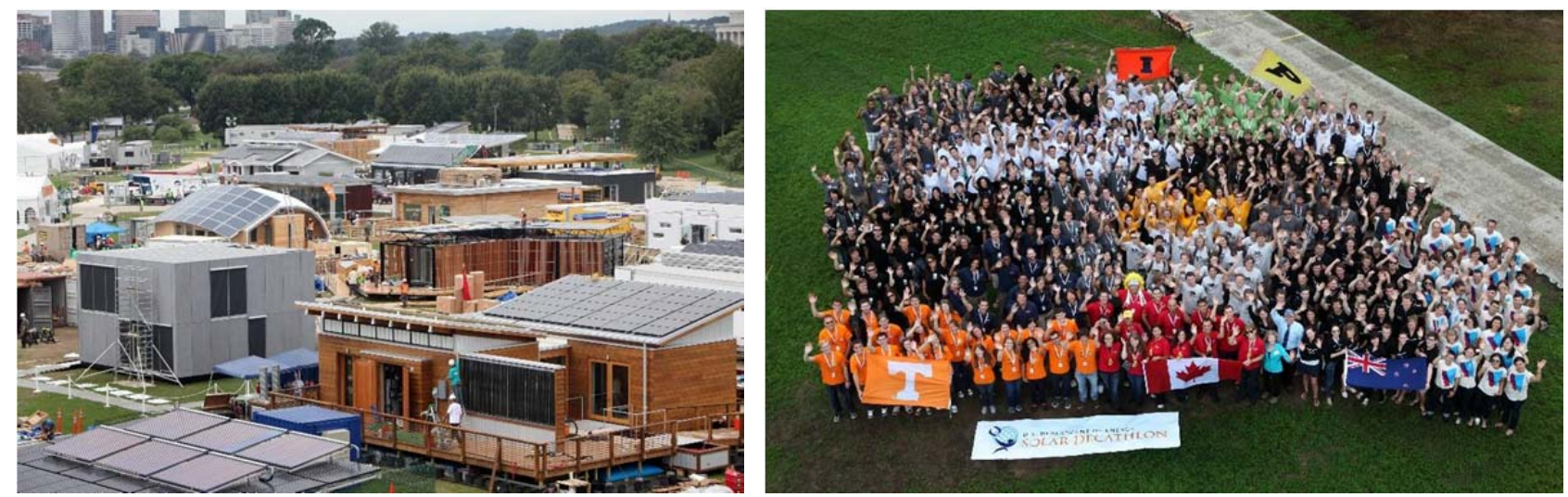

Figure I (on the left). Solar Decathlon houses on the National Mall, Washington D.C. 20I I (image: The Field of Dreams. Photo credit: Stefano Paltera/U.S. Department of Energy Solar Decathlon) Figure 2 (on the right). Solar Decathletes en masse on final prizegiving day, $201 \mathrm{I}$.

(image: Big Team photo. Photo credit: Stefano Paltera/U.S. Department of Energy Solar Decathlon)
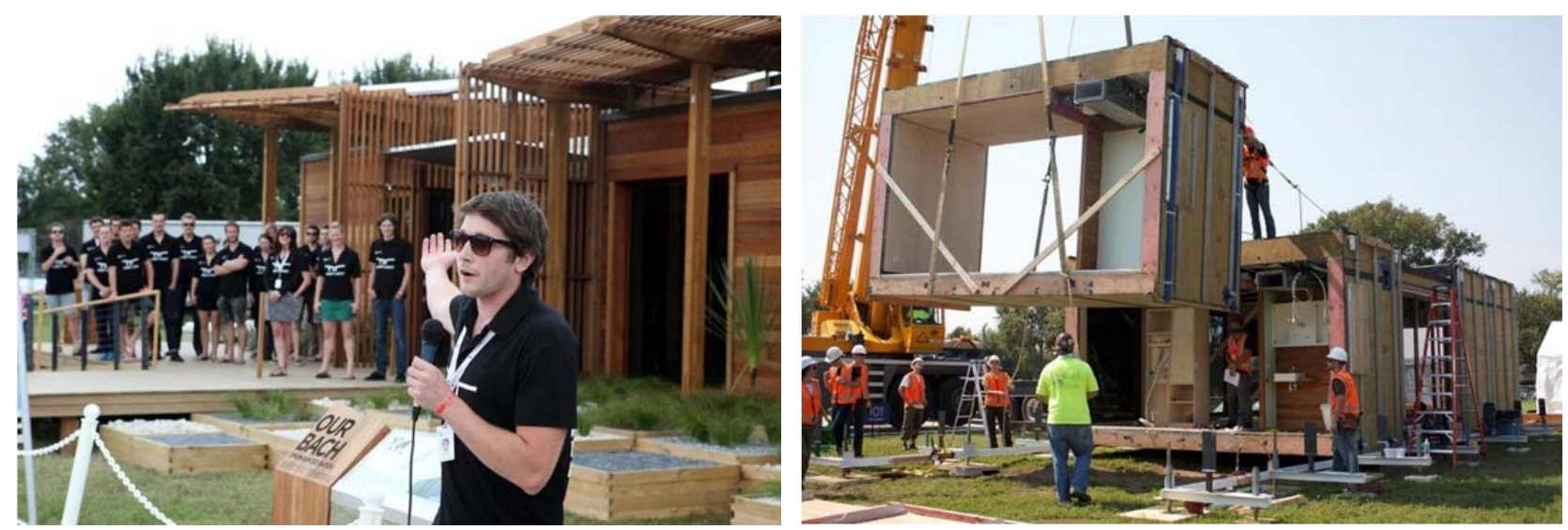

Figure 3 (on the left). Nick Officer giving public talk outside the First Light House, 20I I. (image: Nick. Photo credit: Stefano Paltera/U.S. Department of Energy Solar Decathlon)

Figure 4 (on the right). Installation of module 5 on site, $201 \mathrm{I}$. (image: Firstlight Mod5. Photo credit: Ron Blunt).

\section{Conclusion}

In retrospect, the university should probably have made some different decisions: to further widen the team base, to bring more of the construction 'in-house,' as well as adaptation of the standard student curriculum to allow for such a radically different learning program. While the results from the project were great for the university as public relations, as a means of teaching the project created challenges. Some of the team members who worked the hardest on the project did not achieve the required academic levels in other courses in which they were enrolled, and even failed some courses - purely because of their dedication to the overall project. While that is admirable in the case of the individual student, it is likely seen as less admirable in the case of the student's parents. Educators need to balance that widespread general degree learning with the ability to acquire intensely focused specialist knowledge gained within programs such as the Solar Decathlon. This is not a simple task: the plain truth is that the standard means of running an undergraduate architecture degree program do not necessarily correspond well with the needs of a single-focus interdisciplinary 
and collaborative project such as the Solar Decathlon. Yet the needs and the desires of the students were strong and universities would benefit from evolving their curriculums to adapt to such projects. On hearing about the Solar Decathlon 201 I entry, the question often asked by fresh young students is: 'when are you doing it again?' The answer so far is - 'it is a student-led competition - that is up to you.'
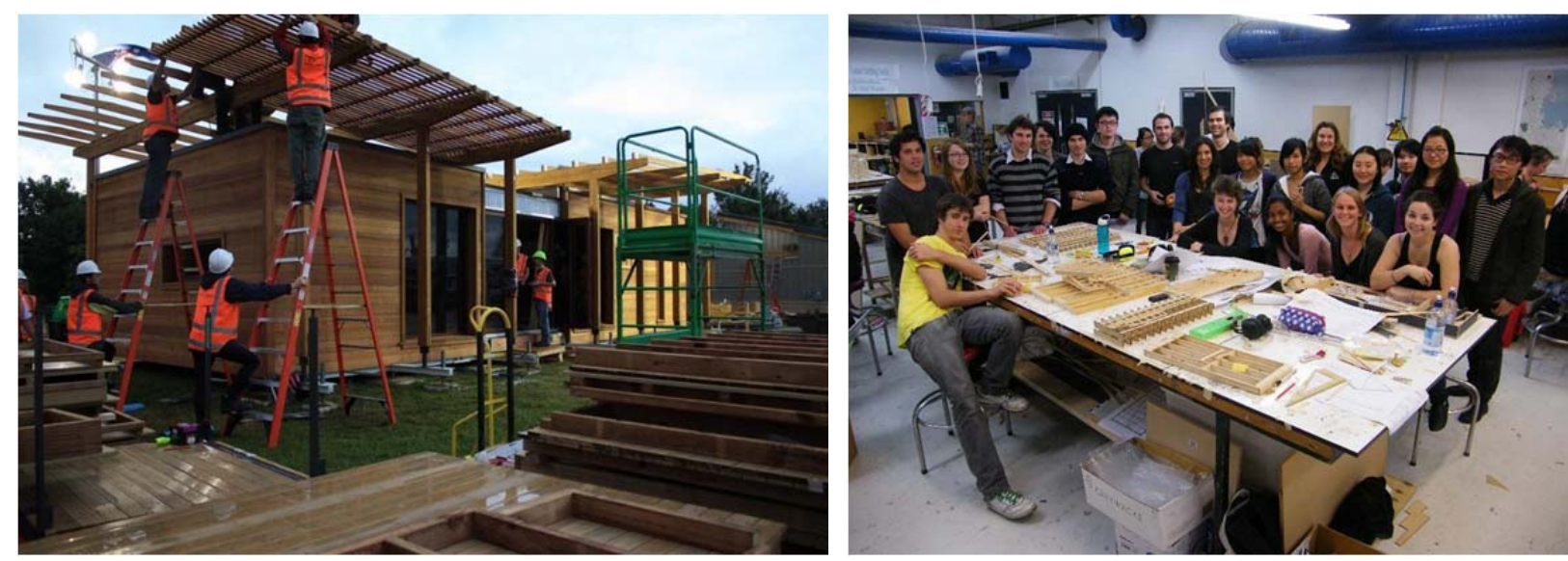

Figure 5 (on the left). Roof panels being assembled on site, 2011. (image: First Light Studs. Photo credit: Ron Blunt).

Figure 6 (on the right). Students building scale model of First Light Junior, to test buildability, 20 I I. (image: FLJteam6. Photo credit: Carrie Speirs).

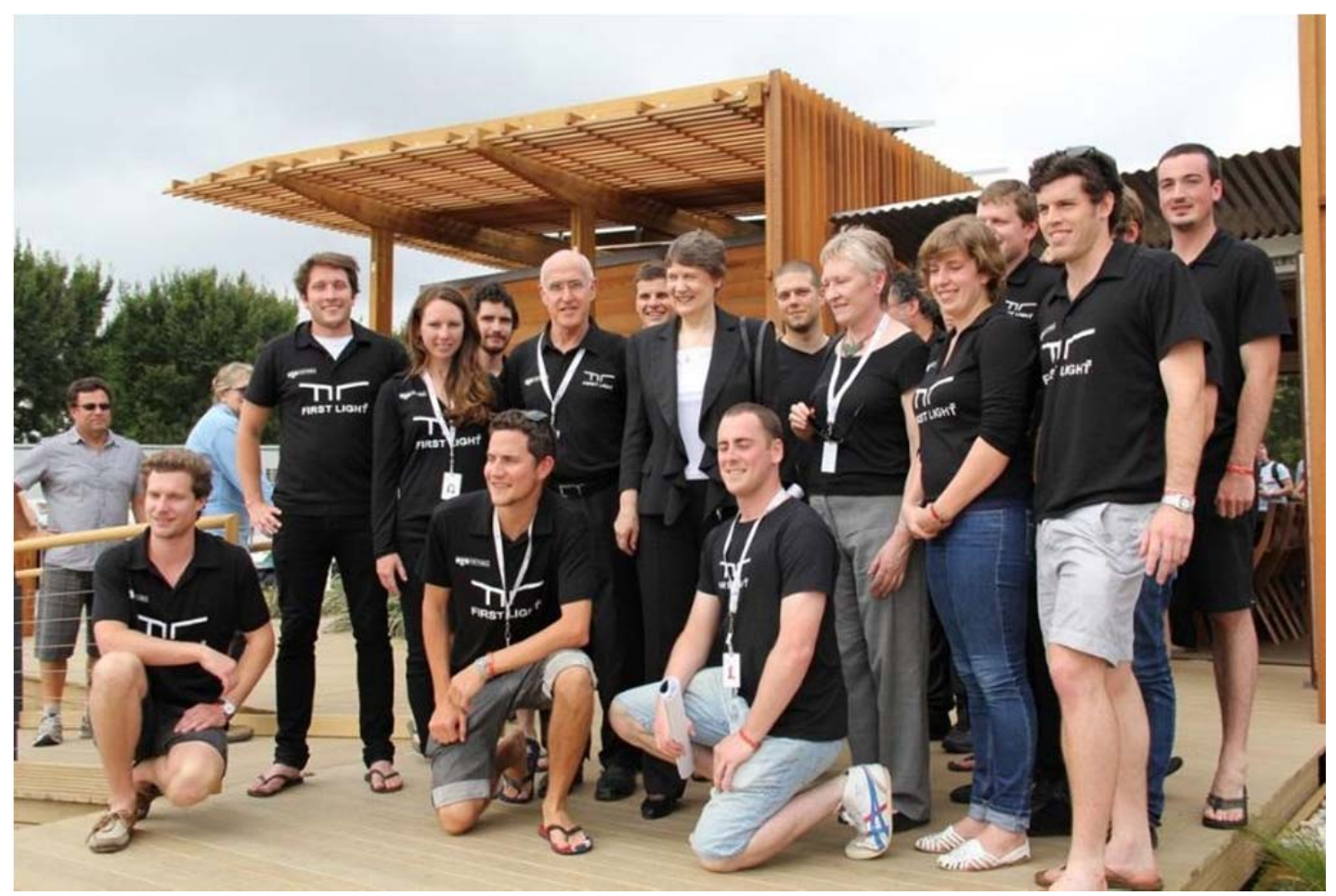

Figure 7. Solar Decathletes gather on front deck with former Prime Minister Helen Clark, 20I I. (image: Firstlight team Helen. Photo credit: First Light). 